\title{
Teaching Effectiveness and Educational Components in Business Education for Liberal Arts Students
}

\author{
Hideki Takei \\ Dept. of Information Technology \& Administrative Management \\ Central Washington University \\ 400 E. University Way, Ellensburg, WA, USA
}

Tel: 1-509-963-2617Ｅ-mail: takeih@cwu.edu

\begin{abstract}
When we teach business courses for liberal arts students, our challenges will be how we can effectively teach students who have different majors, years, interests, and backgrounds in the same class. For example, if we focus on business major students, we may lose other students from different majors. This problem will appear in two critical educational components for liberal arts students, which are teaching and mentoring. This means that we will need two things. One is teaching effectiveness in a whole class and the other is mentoring effectiveness for individual students in the class. Therefore, we must consider class management and individual-level treatments of students carefully in order to improve teaching effectiveness for liberal arts students.

In this paper, our goal is to propose such a comprehensive education model particularly for instructors who teach business courses for liberal arts students. We propose our own comprehensive model based on various literature reviews and empirical studies. Then, we research on effectiveness of our model empirically. Particularly, we try to test if our model could satisfy both teaching and mentoring effectiveness in order to validate our theoretical arguments and this initial educational model for liberal arts students. This study will give us a clearer picture of the comprehensive business education model to make teaching more effective for liberal arts students.
\end{abstract}

Keywords: Blending education, Mentoring, Business education 


\section{Introduction}

Teaching business and business related courses for liberal arts students may be challenging due to differences in experiences, interests, learning skills, and knowledge among students. Especially, since many students may have to take business courses to imply fulfill credits towards their graduations, student motivations and seriousness may be lower than those who are majoring in business. At the same time, general educational approach will be different from business schools where usually the instructors earned their degrees (Akerlind, 2007).

When we teach business courses for liberal arts students, our challenges will be how we can effectively teach students who have different majors, years, interests, and backgrounds in the same class. For example, if we focus on business major students, we may lose other students from different majors. This problem will appear in two critical educational components for liberal arts students, which are teaching and mentoring.

This means that we will need two things. One is teaching effectiveness in a whole class and the other is mentoring effectiveness for individual students in the class. Therefore, we must consider class management and individual-level treatments of students carefully in order to improve teaching effectiveness for liberal arts students.

In this paper, our goal is to propose such a comprehensive education model particularly for instructors who teach business courses for liberal arts students. We propose our own comprehensive model based on various literature reviews and empirical studies. Then, we research on effectiveness of our model empirically. Particularly, we try to test if our model could satisfy both teaching and mentoring effectiveness in order to validate our theoretical arguments and this initial educational model for liberal arts students. This study will give us a clearer picture of the comprehensive business education model to make teaching more effective for liberal arts students.

\section{Teaching Component: Blending Education}

Various studies have discussed that liberal arts students are more ideal to learn conceptual skills and analytical skills for business management because sufficient liberal arts education tend to develop students' abilities of managerial flexibilities in the current dynamic business environments (Gillmor, 1999; Vinten, 2000; Chew and Mclnnis-Bowers, 2004). Especially, this is because general education for liberal arts students usually focuses on finding meaningful and comprehensive connection between various knowledge and realities. Therefore, business instructors should also focus on letting their students connect business and other knowledge to various business environments.

Blending education has been used in classroom in order to enhance students' capability to connect various information and knowledge from other subjects to business studies (Chew \& Mclnnis-Bowers, 2004). The blending education is expected to let students acquire managerial skills such as observation, assessment, flexible adaptations, learning, leadership, and communications through (1) class lectures of solid basic concepts, (2) controversy arguments, (3) group homework and group study, (4) group presentation, and (5) group projects (Light, 2004). The Carnegie Foundation and the Ford Foundation have also pointed 
out the similar educational benefits and supported the blending education. Interestingly, these commissions pointed out that liberal arts students who acquire general knowledge in various fields are more appropriate to be good managers than students who focus exclusively on highly technical knowledge and skills in marketing and business management (Chew \& Mclnnis-Bowers, 2004).

While the blending education has been used widely at higher educational institutions, Birmingham-Southern College's blending education has been studied well and proven that students have learned six business skills such as (1) oral and written communication skills, (2) wider scope of business perspectives, (3) sense of business ethics, (4) critical thinking and assessment, (5) self-assessment and (6) global business perspectives (Chew \& Mclnnis-Bowers, 2004; Edwards, 2007; Myers B \& Myers M, 2007).

\section{Comprehensive Education Model}

In order to build our education model for instructors who teach business for liberal arts students, we had to consider preconditions to let instructors teach and mentor effectively. We designed our model to be able to synchronize teaching and mentoring as Texas State Board for Educator Certification has recommended (Texas Board for Educator Certification, 2003).

Main goals of the education component in our model are to support individual learning of basic marketing concepts and in-the-class cross-disciplinary group learning activities to master the basic concepts and gain some managerial skills. The individual learning can be done by letting students read the textbook before and after sessions and take notes. Sometimes, the individual learning can be even advanced by letting students grade their preand post-chapter exams because they can discover their own learning levels under less stressful conditions. While pre- and post-chapter exams are supposed to be very effective teaching tools, our model has one comprehensive exam at the end of term due to time constraints and variations of educational tools to be tested in our model (Myers B \& Myers M, 2007). This is obviously restriction of educational effectiveness of our model.

Our model emphasizes that instructors must make sure overview, learning goals, and key words of the chapter with their students at a beginning of each chapter. Such key words will be repeated during the entire session of each chapter so that we expect that students can connect key words to various issues and concepts discussed in the sessions. We will also use various media to let students visualize concepts of business in real situations. For example, our model will use textbook cases, news articles, VCR cases, real stores, daily shopping, and lecturers' marketing experiences. During our sessions, we will try to be facilitators instead of being teachers in order to let our students learn actively.

We expect that the cross-disciplinary team activities can expand widths of business knowledge of member students by exchanging various ideas and viewpoints from other students with different disciplines, experiences, and interests. Additionally, they will be able to learn basic managerial skills through various group activities that include selecting cases for class discussions, doing a final project, conducting several group studies, preparing for group presentations, preparing for class facilitations, and performing various other class 
activities (Smart, Kelley, \& Conant, 1999; Hernandez, 2002; Laverie, 2006; Bicen \& Laverie, 2009).

Particularly, our in-the-class cross-disciplinary team learning will let students (1) fully understand theoretical concepts and cases with feeling of reality and (2) acquire various business approaches to make firms more effective in ever changing business environments. Since team members are required to quickly create team environments and be able to exchange various opinions and work collectively, we will design a few ice-breaking class activities in order to help students with such team environments at the beginning of the course. We also designed out-of-the-class cross-disciplinary team learning projects which students can discuss and learn better in less stressful environments.

While our model will continue in-the-class cross-disciplinary team learning until the end of a course, we have more controlled in-the-class activities by the half of the term. Then, we will gradually shift the activities to less controlled activities such as group presentations, work out activities, and class facilitations. At the end of the first half of the course, all teams must submit group activities evaluation reports to their instructor. The instructor should use the performance reports to directly give suggestions, encouragement, and recognitions to each team.

In addition to the performance reports, cross-disciplinary teams will be asked to invite the lecturer to their group studies at least 4 times per course, which will be 2 times for the first half of the course and another 2 times for the rest of the course. We are expected to (1) participate in the group studies as a member and (2) offer direct suggestions and recognitions to the groups. This will give us constant chances for mentoring groups.

Our model included one ice breaking activity, two research projects, four in-class workshops, two out-of-class workshops, and a final comprehensive exam. The ice breaking activity was the first group activity, using cross-disciplinary teams, and theoretically helped create a comfortable environment in support of good rapport between participants and instructors.

The two research projects were designed to let students understand a complete process of business development and management. The first project was called as community business consulting in which each team had to go to downtown for their own market research about business environments, market environments, marketing activities of local businesses, location, and consumer behaviors. This is highly connected to the second research project since this is a starting ground to complete the second project called as business development planning.

The second project was a subsequent project to the first one and designed to let students sdiscover business opportunities and develop a new business in the downtown area based on their own market research. While they must always rely on the facts on their market research in order to develop a new business, they could be very creative in the design of their new venture as long as their plans satisfy market desirability, business feasibility, and leader/manager accountability.

Before each project, students must participate two in-class workshops to discuss and review 
basic learning processes of each project. The instructor was asked to discuss both technical knowledge and the basic process of market research and business development. These workshops were closely supervised and facilitated by the instructor so that the instructor will be comfortably invited to students' discussions. We believe that the instructor could make better relationship with students for mentoring quickly through these workshops.

In addition to the in-class workshops, we designed two out-of-class workshops prior to each team heading downtown for the field study and in developing the business plan. We expected the instructor could participate in these workshops as an equal team member who could also pose questions, concerns, ideas, and suggestions in less formal environments than classrooms. This is an important point to created opportunities for students to collaborate and interact with their instructor as a partner and participant (Hernandez, 2002; Taras, 2002; Scribner, Baker \& Howe, 2003; Laverie, 2006).

\section{Methodology}

There are three categories of education goals of our model so that we can estimate performance of our model by testing these three goals. First category is called as education performance meaning how much students should learn basic knowledge, technical skills, basic application expertise, and a complete process of business and marketing (Day \& Cordon, 1993; Stephani, 1998; Trotter, 2006; and Jeltova, et al., 2007). Second category is called as mentoring performance meaning how much instructors should develop and maintain relationships with students. Ideally, we are looking for establishing and maintaining "personal level communications” with the instructors (Light, 2004; and Cox \& Orehovec, 2007). Last category is called as student satisfaction meaning how much students should be satisfied with learning, team projects, interactions with team mates and instructors, or any other activities of the blending education of our model (J.D. Day \& Cordon, 1993; Jeltova \& et al., 2007).

Once we received official human subject permission, we simply chose a basic business course which many students tend to take to satisfy their credit requirements no matter what majors they are in at a liberal arts institution. As we mentioned, these courses have students from various disciplines, more than $50 \%$ of the students in a class are not majoring business. The course has two sections and there were forty four students in the first section and forty eight students in the second section.

We used questionnaires with fifteen Likert scale questions as a main formative tool. The Likert scale has 5 different answers and each student would select one of the following responses: 5 (Strongly agree), 4 (Agree), 3 (Neutral), 2 (Disagree), and 1 (Strongly disagree). Additionally, we used the final exam as summative data (Yorke, 2003; Bloxham \& West, 2004). When students completed the first project in class, we distributed and collected the questionnaires. When they completed the second project, we distributed and collected identical questionnaires in order to see continuous performances of our model.

We used a pooled-variance t-test to examine the difference between two mean values from the two sections. The pooled-variance t-test allowed us to determine the existence of any significant difference between the means of the two sections (Berenson, Levine, \& Krehbiel, 2006; Wagner, 1992). Since the t-test simply measures the compared mean values of first 
section and second section, we used a two-tailed non-directional analysis at 0.05 and 0.01 levels of significance. In addition to the t-test, we checked the observed significance level of our mean values by p-value. Our critical p-value was 0.05 given sufficient evidence existed to conclude that the mean value of the first section is not equal to the mean value of the second section, especially if the p-value is smaller than 0.05 (Berenson, Levine, \& Krehbiel, 2006; Wagner, 1992).

\section{Discussions}

Our students in both sections seemed to learn very well through the two projects. In addition to this self-reported learning performance, they seemed to be more confidence in what they learned and experienced in their market research. While student confidence gained from the second project was very high, the result did not achieve levels of statistical significance. Please see four tables in our appendix section.

It seemed like our students realized connections between real businesses and outcomes and experiences from the two projects. They seemed to gain reasonable confidence with further applications of learned knowledge, experiences, approaches, and technical knowledge in the two projects. Indeed, we may say such confidence could be emerged from their recognition of the practical usefulness of the class-related experiences to their future career(s). In fact, multiple student comments advised the instructor to keep these projects into the next semester.

While our model seemed to perform reasonably well, there are several concerns about performances of learning through cross-disciplinary team activities. While students seemed to be satisfied well with two workshops for each project, they showed weaker satisfactions with the out-of-class workshops. This presented a concern given the out-of-class workshops were specifically designed as "accelerators" in establishing appropriate relationships with students, transforming the relationships to a more personal level via mentoring, offer a personalized level of attention, and elicit suggestions to and from each team member. Consistently, the students expressed preferences to convert the out-of-class workshops to in-class workshops. While this preference was not statistically significant, the students scored the out-of-classroom workshops as neutral to agree, when responding to the question, "all out-of-class workshops should be done during the class.”

We noticed student preference for the in-class workshops when we received numerous student e-mails and visits expressing concerns about the out-of-class workshops. Almost all of the concerns surrounded a preference to perform all workshops during the class or if the instructor could change the out-of-class workshops to the in-class workshops. According to the s-mails and conversations with students, we found that this dissatisfaction came from a technical problem with difficulty to arrange time for the out-of-class workshops due to various timetables of curriculums in various disciplines.

Learning through cross-disciplinary team activities is considered one of the student-focused advantages with business education for liberal arts students. While our data sis not satisfy statistical significance, our students seemed to enjoy their cross-disciplinary teams and activities. This is important since they enjoyed the cross-disciplinary team activities even if they had serious problems to arrange time for meetings. This means that we could assume 
that students would be highly satisfied from the cross-disciplinary activities once we come up with ideas to solve $t$ he arrangement problems.

As figure 1 shows, our summative data showed that the experimental sample of students reflects somehow increased knowledge acquisition, when compared to students in the past semesters. The average score of the two sections in term one was 81.51, in term two was 86.77, in term three was 85.44 , and in term four was 91.08 . We said student learning was somehow increasing because average score of the first section was respectively 80.01 in term one, 89.14 in term two, 84.21 in term three, and 89 in term four. In this situation, we could not observe constant improvement of student learning in the section one. We consider the summative data might not capture overall and practical learning and satisfaction of students through our model. This could be because of types of questions or fundamental differences in nature of exams from other elements of the blending education.

\section{Conclusion}

Two education components, teaching and mentoring, are indeed very important especially to teach liberal arts students. Our model seemed to work reasonably well as a valid effective educational model for the students; however, we could not confirm our model's effectiveness by our summative performance evaluation tool. In addition, there were practical difficulties with out-of-class workshops and cross-disciplinary team activities. Our suggestion is that instructors should develop their own style in ensuring personal level communications with students in and out of class. We also suggest that cross -disciplinary team activities must be carefully introduced under careful supervisions and arrangement by instructors.

\section{References}

Akerlind, G. (2007). Constraints on academics' potential for developing as a teacher. Studies in Higher Education , 21-37.

Bicen, P., \& Laverie, D. A. (2009). Group-based assessment as a dynamic approach to marketing education. Journal of Marketing Education, 31(2), 96-108.

Bloxham, S., \& West, A. (2004). Understanding the rules of the game: Making peer assessment as a medium for developing students' conceptions of assessment. Assessment and Evaluation in Higher Education, 29(6),721-733.

Brenson, M. L., Levine, D. M., \& Krehbiel, T. C. (2009). Basic Business Statistics. $11^{\text {th }}$ ed. Pearspn-PrenticeHall, NJ.

Chew, E. B., \& Mclnnis-Bowers, C. (2004). Blending Liberal Arts \& Business Education. Liberal Education , 56-62.

Cox, B. E., \& Orehovec, E. (2007). Faculty-student interaction outside the classroom: A typology from a residential college. The review of higher education , 343-362.

Day, J.D., \& Cordon, L. A. (1993). Static and dynamic measures of ability; An experimental comparison. Journal of Educational Psychology, 85(1), 75-82.

Edwards, N.M. (2007). Student self-grading in social statics. Ollege Teaching, 55(2), 72-76. 


\section{Macrothink

Gillmor, V. (1999, April 18). Newest Technology, Plus liberal arts, Makes for success colleges increasingly integrating business courses and liberal arts. Chicago Tribune , 3.

Hernandez, S. A. (2002). Team learning in a marketing principles course:Cooperative structure that facilitate active learning and higher level thinking. Journal of Marketing Education, 24(1), 73-85.

Jeltova, G. L., Birney, D., Fredine, N., Jarvin, L., Sternberg, R. J., \& Grigorenko, E. L. (2007). Dynamic assessment as a process-oriented assessment in educational settings. Advances in Speech-Language Pathology, 9, 273-285.

Laverie, D. A. (2006). In-class active cooperative learning: A way to build knowledge and skills in marketing courses. Marketing Education Review,16(2), 59-76.

Light, R. J. (2004). Making the Most of College. Massachusetts: Harvard University Press.

Myers, C. B., \& Myers, S. M. (2007). Assessing assessments: The effects of two exam formats on course achievement and evaluation. Innovative Higher Education , 227-236.

Scribner, L. L., Baker, T. L., \& Howe, V. (2003). Efficacy of group projects in support skills acquisition: Student vs. alumni perceptions. Marketing Education Review, 13(1), 59-66.

Smart, D. T., Kelley, C. A., \& Conant, J. S. (1999). Marketing education in the year 2000: Changes observed and challenges anticipated. Journal of Marketing Education, 21(3), 206-216.

Stephanie, L. A. J. (1998). Assessment in partnership with learners. Assessment and Evaluation in Higher Education, 23(4), 339-350.

Taras, M. (2002). Using assessment for learning and learning from assessment. Assessment and Evaluation in Higher Education, 27, 501-510.

Texas State Board for Educator Certification. (2003). Marketing Education Standards: Final, Approved on Juanuary 9, 2004. Marketing Education Standards.

Trotter, E. (2006). Student perceptions of continuous summative assessment. Assessment and Evaluation in Higher Education, 31, 505-521.

Vinten, G. (2000). The business school in the new millennium. The International Journal of Educational Management , 180.

Wagner, S. F. (1992). Introduction to Statistics. Harper Collins, NY.

Yorke, M. (2003). Formative assessment in higher education: Moves towards theory and the enhancement of pedagogic practice. Higher Education, 45(4), 477-501. 
Table 1. Results of the pooled-variance t-test for the first project

\begin{tabular}{|c|c|c|c|c|c|c|}
\hline \multirow[t]{2}{*}{ Questions } & \multirow{2}{*}{$\begin{array}{c}\text { T-stat } \\
0.05\end{array}$} & \multicolumn{5}{|c|}{ T-stat } \\
\hline & & $\mathrm{T}$ & $\mathrm{P}$ & 0.01 & $\mathrm{~T}$ & $\mathrm{P}$ \\
\hline Final & 1.986 & $-2.71^{*}$ & $0.00 B^{*}$ & 2.631 & $-2.71 * *$ & $0.00 B^{* *}$ \\
\hline $\begin{array}{l}\text { Learned basic process of market research }[E] \\
\text { Understood the instructor's expectations to th is }\end{array}$ & 1.986 & $-3.11^{*}$ & $0.002^{*}$ & 2.631 & $-3.11^{* *}$ & $0.002 * *$ \\
\hline $\begin{array}{l}\text { project (M) } \\
\text { Learned technical knowledge and skils of }\end{array}$ & 1.986 & $4.609^{*}$ & $0.0000^{*}$ & 2.631 & $4.609^{* *}$ & $0.0000^{* *}$ \\
\hline market research $(\mathrm{E})$ & 1.986 & -0.821 & 0.4137 & 2.631 & -0.821 & 0.4137 \\
\hline Gained confidence in your market research $[\mathrm{E}]$ & 1.986 & $-2.036^{*}$ & $0.0446^{*}$ & 2.631 & -2.036 & 0.0446 \\
\hline $\begin{array}{l}\text { Get motivated for this project (M) } \\
\text { Enjoyed personal level commu nication with the }\end{array}$ & 1.986 & 0.3753 & 0.7082 & 2.631 & 0.3753 & 0.7082 \\
\hline instructor $(\mathrm{M}, \mathrm{s})$ & 1.986 & $3.8059^{*}$ & $0.0003^{*}$ & 2.631 & $3.8059^{* *}$ & $0.0003 * *$ \\
\hline $\begin{array}{l}\text { Information sharing among team me mbers (M) } \\
\text { Understood value and meaning of market }\end{array}$ & 1.986 & $3.99 B^{*}$ & $0.0001^{*}$ & 2.631 & $3.998^{* *}$ & $0.0001 * *$ \\
\hline $\begin{array}{l}\text { research }[E] \\
\text { This project should be kept for the next }\end{array}$ & 1.986 & $3.733^{*}$ & $0.0003^{*}$ & 2.631 & $3.733^{* *}$ & $0.0003^{* *}$ \\
\hline $\begin{array}{l}\text { semester }(E, 5) \\
\text { All out-of-class workshops should be done in }\end{array}$ & 1.986 & $2.93^{*}$ & $0.0042^{*}$ & 2.631 & $2.93^{* *}$ & $0.0042 * *$ \\
\hline $\begin{array}{l}\text { class }[\mathrm{E}, \mathrm{M} \text { ) } \\
\text { Enjoyed working with my cross-disciplinary team }\end{array}$ & 1.986 & 0.085 & 0.9323 & 2.631 & 0.085 & 0.9323 \\
\hline members $[\mathrm{E}]$ & 1.986 & -1.174 & 0.2431 & 2.631 & -1.174 & 0.2431 \\
\hline This project will be useful in mycareer [E] & 1.986 & $-2.752^{*}$ & $0.0071^{*}$ & 2.631 & $-2.752^{* *}$ & $0.0071 * *$ \\
\hline Satisfied with workshops (E, M, S) & 1.986 & $-4.037^{*}$ & $0.0001^{*}$ & 2.631 & $-4.037^{* *}$ & $0.0001 * *$ \\
\hline $\begin{array}{l}\text { Satisfied with this project (5) } \\
\text { Gained confidence in ano ther market research }\end{array}$ & 1.986 & $2.799^{*}$ & $0.0062^{*}$ & 2.631 & $2.799^{* *}$ & $0.0062^{* *}$ \\
\hline (E) & 1.986 & $-4.541^{*}$ & $0.0000^{*}$ & 2.631 & $-4.541 * *$ & $0.0000^{* *}$ \\
\hline
\end{tabular}

Table 2. Descriptive statistics for the first project

\begin{tabular}{|c|c|c|c|c|c|}
\hline Questions & Sample & Mean & SD & Kurtosis & Skewness \\
\hline \multirow[t]{2}{*}{ Final } & 44 & 89 & 6.8318 & 2 & -1.3896 \\
\hline & 48 & 93.15 & 7.77 & 1.42 & -1.46 \\
\hline \multirow[t]{2}{*}{ Learned basic process of market research } & 44 & 4 & $0.5 B B B$ & 1 & -0.5325 \\
\hline & 48 & 4.4 & 0.64 & -0.56 & -0.59 \\
\hline \multicolumn{6}{|l|}{ Understood the instructor's expectations to th is } \\
\hline \multirow[t]{2}{*}{ project } & 44 & 5 & 0.7624 & 2 & -1.4838 \\
\hline & 48 & 4.33 & 0.63 & -0.61 & -0.39 \\
\hline \multirow{3}{*}{$\begin{array}{l}\text { Learned technical knowledge and skills of market } \\
\text { research }\end{array}$} & & & & & \\
\hline & 44 & 4 & 0.685 & -1 & -0.6161 \\
\hline & $4 B$ & 4.13 & 0.82 & 3.14 & -1.22 \\
\hline \multirow[t]{2}{*}{ Gained confidence in market research } & 44 & 4 & 0.8053 & -1 & -0.3026 \\
\hline & 48 & 4.35 & 0.84 & 5.07 & -1.9 \\
\hline \multirow[t]{2}{*}{ Get motivated for this project } & 44 & 4 & 0.7721 & -1 & -0.1574 \\
\hline & 48 & 3.94 & 0.76 & -0.42 & -0.2 \\
\hline \multirow{3}{*}{$\begin{array}{l}\text { Enjoyed personal level communication with the } \\
\text { instructor }\end{array}$} & & & & & \\
\hline & 44 & 5 & 0.7313 & 2 & -1.4947 \\
\hline & 48 & 4.44 & 0.68 & -0.44 & -0.82 \\
\hline \multirow[t]{2}{*}{ Information sharing among team me mbers } & 44 & 5 & 0.5865 & 0 & -1 \\
\hline & 48 & 4.44 & 0.74 & 1.26 & -1.25 \\
\hline \multirow[t]{2}{*}{ Understood value and meaning of market research } & 44 & 5 & 0.6647 & 0 & -0.9953 \\
\hline & 48 & 4.5 & 0.62 & -0.23 & -0.84 \\
\hline \multirow[t]{2}{*}{ This project should be kept for the next semester } & 44 & 5 & 0.5865 & 0 & 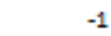 \\
\hline & 48 & 4.6 & 0.71 & 3.39 & -1.9 \\
\hline \multirow[t]{2}{*}{ All out-of-class workshops should be done in class } & 44 & 3 & 1.025 & 0 & 0.3937 \\
\hline & 48 & 2.98 & 1.21 & -0.66 & 0.27 \\
\hline \multicolumn{6}{|l|}{ Enjoyed working with my cross-disciplinary team } \\
\hline \multirow{2}{*}{ members } & 44 & 4 & 0.9732 & 2 & -1.5386 \\
\hline & 48 & 4.25 & 1.06 & 1.22 & -1.42 \\
\hline \multirow[t]{2}{*}{ This project will be useful in mycareer } & 44 & 4 & 0.7537 & 0 & -0.5343 \\
\hline & 48 & 4.42 & 0.71 & -0.56 & -0.81 \\
\hline \multirow[t]{2}{*}{ Satisfied with workshops } & 44 & 4 & 0.68 & 2 & -1.0133 \\
\hline & 48 & 4.56 & 0.65 & 0.37 & -1.21 \\
\hline \multirow[t]{2}{*}{ Satisfied with this project } & 44 & 5 & 0.5906 & 0 & -0.7095 \\
\hline & 48 & 4.63 & 0.67 & 1.15 & -1.57 \\
\hline \multirow[t]{2}{*}{ Gained confidence in ano ther market research } & 44 & 4 & 0.6954 & 0 & -0.8318 \\
\hline & 48 & 4.6 & 0.57 & 0.37 & -1.13 \\
\hline
\end{tabular}


Table 3. Results of the pooled-variance t-test for the second project

\begin{tabular}{|c|c|c|c|c|c|c|}
\hline \multirow[t]{2}{*}{ Questions } & T-stat & \multicolumn{5}{|c|}{ T-stat } \\
\hline & 0.05 & $\mathrm{~T}$ & $\mathrm{P}$ & 0.01 & T & $\mathrm{P}$ \\
\hline Learned basic process of business planning (E) & & - & & & - & \\
\hline Understood the instructor's expectations to this & 1.986 & $4.282^{*}$ & $0.0000^{*}$ & 2.631 & $4.282^{* *}$ & $0.0000^{* *}$ \\
\hline $\begin{array}{l}\text { project }(M) \\
\text { Learned technical knowledge and skills of }\end{array}$ & 1.986 & $4.565^{*}$ & $0.0000^{*}$ & 2.631 & $4.565^{* *}$ & $0.0000^{* *}$ \\
\hline business planning $(\mathrm{E})$ & 1.986 & $2.291^{*}$ & $0.0242^{*}$ & 2.631 & -2.291 & 0.0242 \\
\hline Gained confidence in your business planning (E) & 1.986 & -1.567 & 0.1205 & 2.631 & -1.567 & 0.1205 \\
\hline $\begin{array}{l}\text { Get motivated for this project (M) } \\
\text { Enjoyed personal level communication with the }\end{array}$ & 1.986 & -0.211 & 0.8327 & 2.631 & -0.211 & 0.8327 \\
\hline instructor $(M, 5)$ & 1.986 & $3.771^{*}$ & $0.0002^{*}$ & 2.631 & $3.771 * *$ & $0.0002^{* * *}$ \\
\hline $\begin{array}{l}\text { Information sharing among team members (M) } \\
\text { Understood value and meaning of business }\end{array}$ & 1.986 & -1.915 & 0.0586 & 2.631 & -1.915 & 0.05 \\
\hline $\begin{array}{l}\text { planning (E) } \\
\text { This project should be kept for the next semester }\end{array}$ & 1.986 & 4.708* & $0.0000^{*}$ & 2.631 & $4.708^{* *}$ & 00 \\
\hline$(E, S)$ & 1.986 & $2.927^{*}$ & $0.0043^{*}$ & 2.631 & $2.927^{* *}$ & $0.0043^{* *}$ \\
\hline $\begin{array}{l}\text { All out-of-class workshops should be done in } \\
\text { class }(E, M)\end{array}$ & 1.986 & -0.231 & 0.8176 & 2.631 & -0.231 & 0.8176 \\
\hline $\begin{array}{l}\text { Enjoyed working with my cross-disciplinary team } \\
\text { members (E) }\end{array}$ & 1.986 & -1.172 & 0.2441 & 2.631 & -1.172 & 0.2441 \\
\hline This project will be useful in mycareer $(E)$ & 1.986 & $2.563^{*}$ & $0.012^{*}$ & 2.631 & -2.563 & \\
\hline Satisfied with workshops (E, M, 5) & & - & & & - & \\
\hline & 1.986 & $4.054^{*}$ & $0.0001^{*}$ & 2.631 & $4.054^{* *}$ & $0.0001 * *$ \\
\hline $\begin{array}{l}\text { Satisfied with this project }(5) \\
\text { Gained confid ence in ano ther business planning }\end{array}$ & 1.986 & $3.415^{*}$ & $0.0009^{*}$ & 2.631 & $3.415^{* *}$ & 0.0009 \\
\hline (E) & 1.986 & $4.044^{*}$ & $0.0001^{*}$ & 2.631 & $4.044^{* *}$ & $0.0001^{* *}$ \\
\hline
\end{tabular}

Table 4. Descriptive statistics for the second project

\begin{tabular}{|c|c|c|c|c|c|}
\hline Questions & Sample & Mean & 50 & Kurtosis & Skewness \\
\hline \multirow[t]{2}{*}{ Learned basic process of business planning } & 44 & 4 & 0.5865 & -1 & -0.4478 \\
\hline & 48 & 4.54 & 0.62 & 0.06 & -1.01 \\
\hline \\
\hline \multirow[t]{2}{*}{ this project } & 44 & 5 & 0.6287 & 0 & -0.882 \\
\hline & 48 & 4.38 & 0.67 & 1.86 & -1.05 \\
\hline \multirow{3}{*}{$\begin{array}{l}\text { Learned technical knowledge and skills of } \\
\text { business planning }\end{array}$} & & & & & \\
\hline & 44 & 4 & 0.7338 & 1 & -0.9037 \\
\hline & 48 & 4.35 & 0.73 & 0.95 & -1.01 \\
\hline \multirow[t]{2}{*}{ Gained confidence in business planning } & 44 & 4 & 0.7078 & -1 & -0.5484 \\
\hline & 48 & 4.27 & 0.92 & 3.04 & -1.62 \\
\hline \multirow{2}{*}{ Get motivated for this project } & 44 & 4 & 0.9103 & -1 & -0.5732 \\
\hline & 48 & 4.04 & 0.9 & 1.04 & -0.82 \\
\hline \\
\hline \multirow[t]{2}{*}{ the instructor } & 44 & 5 & $0.698 B$ & 0 & -1.0707 \\
\hline & 48 & 4.42 & 0.77 & -0.7 & -0.89 \\
\hline \multirow[t]{2}{*}{ Information sharing among te am members } & 44 & 4 & 0.685 & -1 & -0.6161 \\
\hline & 48 & 4.31 & 0.85 & 0.46 & -1.09 \\
\hline \multicolumn{6}{|l|}{ Understood value and meaning of business } \\
\hline \multirow[t]{2}{*}{ planning } & 44 & 5 & 0.627 & 0 & -1.068 \\
\hline & 48 & 4.29 & 0.8 & -0.04 & -0.85 \\
\hline \multicolumn{6}{|l|}{ This project should be kept for the next } \\
\hline \multirow{2}{*}{ semester } & 44 & 5 & 0.7309 & 2 & -1.579 \\
\hline & 48 & 4.56 & 0.71 & 2.77 & -1.71 \\
\hline \multirow{3}{*}{$\begin{array}{l}\text { All out-of-class workshops should be done in } \\
\text { class }\end{array}$} & & & & & \\
\hline & 44 & 3 & 1.1281 & -1 & 0.0395 \\
\hline & 48 & 3.06 & 1.34 & -1.16 & -0.01 \\
\hline \multirow{3}{*}{$\begin{array}{l}\text { Enjoyed working with my cross-disciplinary } \\
\text { team members }\end{array}$} & & & & & \\
\hline & 44 & 4 & 0.9783 & 2 & -1.3693 \\
\hline & 48 & 4.25 & 1.06 & 1.22 & -1.42 \\
\hline \multirow[t]{2}{*}{ This project will be useful in mycareer } & 44 & 4 & 0.7338 & 1 & -0.7142 \\
\hline & 48 & 4.4 & 0.76 & 0.74 & -1.12 \\
\hline \multirow[t]{2}{*}{ Satisfied with workshops } & 44 & 4 & 0.6249 & 0 & $-0.628 B$ \\
\hline & 48 & 4.54 & 0.65 & 0.18 & -1.13 \\
\hline \multirow[t]{2}{*}{ Satisfied with this project } & 44 & 5 & 0.57933 & 1 & -1.2197 \\
\hline & 48 & 4.56 & 0.65 & 0.37 & -1.21 \\
\hline \multicolumn{6}{|l|}{ Gained confid ence in another business } \\
\hline \multirow[t]{2}{*}{ planning } & 44 & 5 & 0.6283 & 0 & -0.973 \\
\hline & 48 & 4.46 & 0.65 & -0.36 & -0.81 \\
\hline
\end{tabular}




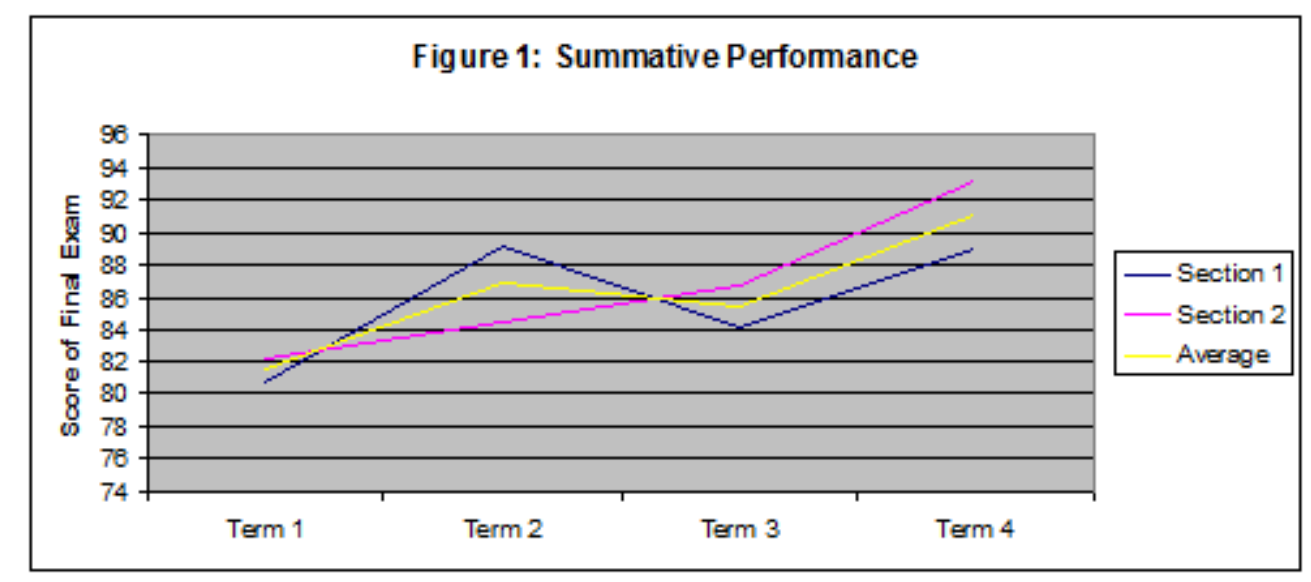

Figure 1. Summative performance

\section{Copyright Disclaimer}

Copyright reserved by the author(s).

This article is an open-access article distributed under the terms and conditions of the Creative Commons Attribution license (http://creativecommons.org/licenses/by/3.0/). 